Received: October 22, 2017

Revision received: May 7, 2018

\title{
Research-based Teaching Model of Ideological and Political Course Under Computer Network Environment
}

\author{
Dongbing $\mathrm{Lu}^{1}$ \\ Bengbu Medical College
}

\begin{abstract}
Ideological and political course is the main carrier of ideological and political education for students. This paper firstly introduces the theoretical basis and practical basis of the research-based (guidance-inquiry-based) teaching model, and then analyses the new opportunities and challenges for the ideological and political education at the Internet era. Finally, it elaborates the application of guidance-inquiry-based teaching model in the ideological and political education of colleges and universities at the Internet age.
\end{abstract}

\section{Keywords}

Network Environment $\bullet$ Ideological and Political Course $\bullet$ Research-Based Teaching

\footnotetext{
${ }^{1}$ Correspondence to: Dongbing Lu (MA), Bengbu Medical College, Bengbu 233030, China. Email: 602575422@qq.com

Citation: Lu, D.B. (2018). Research-based Teaching Model of Ideological and Political Course Under Computer Network Environment. Educational Sciences: Theory \& Practice, 18(5), 1784-1791. http://dx.doi.org/10.12738/estp.2018.5.078
} 
The rapid development of network technology has greatly accelerated the progress of basic education curriculum reform. Research-based learning is aimed at transforming teachers' teaching methods and students' learning methods, and cultivating students' innovative spirit and practical ability. It is a hot and difficult topic in the reform of basic education curriculum both at home and abroad (Lee \& Tai, 2008). At present, the integration of research-based learning and information technology, especially Internet technology, has attracted more and more attention by educators. The development of network technology not only poses new challenges to ideological and political teaching, but also creates more favourable conditions. More attention should be paid to the study of the ideological and political teaching model under the network environment, constructing one research-based teaching model of the ideological and political education under the multimedia network environment on the basis of constructivism and humanism theory. It can not only exert the leading role of the teacher, but also fully embody the students' main cognitive role. The teaching model should be designed according to the teaching objectives, teaching content and the characteristics of teaching objects; applying scientific system viewpoints and methods, selecting and designing teaching media information reasonably, the optimized teaching system structure can be formed, which includes multiple correlated and interacted factors such as teachers, students, teaching materials and media, etc. (Zhang, 2016; Raghavan, Ganesh, Raghavan \& Ganesh, 2015).

\section{Teaching Mode Design}

The design of teaching model should be based on the teaching objectives, teaching content and characteristics of teaching objects, apply scientific and systematic perspectives and methods, reasonably select and design teaching media information, and develop an optimized teaching system structure, which includes multiple factors such as teachers, students, teaching materials and media, which are correlative and interactional (Lagrosen, Seyyed-Hashemi \& Leitner, 2004). The design of teaching mode directly affects the teaching effect. Based on the basic law of students' cognitive activities, and combining the characteristics of ideological and political teaching, the author constructs a research-based teaching model of ideological and political courses based on network (Karatas, Alci, Balyer \& Bademcioglu, 2016).

\section{Develop teaching objectives according to the nature of the course}

The teaching of ideological and political courses requires the development of the political theory function while paying attention to cultivating students' humanistic care. It is an important task to combine the social educational function of ideological and political courses with the individual needs of students in teaching. Therefore, at the beginning of the development of teaching objectives, we must pay attention to the individual development of each student as an important goal. While improving their political accomplishment, we must also pay attention to cultivating their ideological and moral qualities, and develop good social behaviors, and make them become the pillars of society in the future. 


\section{Develop teaching tasks according to the syllabus}

Firstly, teachers should develop detailed teaching content based on the textbook. To adopt the MOOC mixed teaching mode, it is necessary to adopt the problem-oriented topic teaching mode. These topics are based on independent knowledge points. Each knowledge point is divided into modules according to logical relationships. Each module is divided into several small knowledge points for students to learn and test independently. Secondly, teachers collect teaching information resources according to the teaching content. Finally, teachers should prepare the teaching PPT, micro-course, mid-term and final-term tests according to the teaching resources for testing the learning effect of students.

\section{Develop different teaching modules based on the teaching form}

In terms of the teaching form, the ideological and political course can be divided into four teaching function modules, namely the teacher online module, teacher classroom module, student online module, and student classroom module. The four modules have different functions, with varied teaching tasks (Figure 1). This paper firstly introduces the theoretical basis and practical basis of the research-based (guidance-inquiry-based) teaching model, and then analyses the new opportunities and challenges for the ideological and political education at the Internet era. Finally, it elaborates the application of guidance-inquiry-based teaching model in the ideological and political education of colleges and universities at the Internet age.

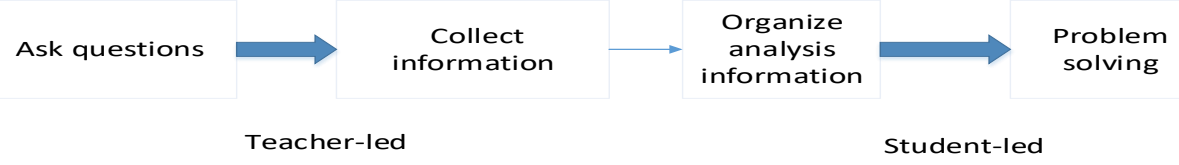

Figure 1. The four modules in the teaching mode design.

\section{Theory and Research Background}

\section{Constructivism learning theory}

Constructivism learning theory emphasizes student-centeredness and encourages students to actively explore, discover, and construct knowledge. The theory argues that learning is not just about teachers imparting knowledge to students, but that students use the necessary learning resources for the process of self-knowledge construction with the guidance of teachers and the help of classmates. This theory highlights the subjectivity and autonomy of students in the process of constructing meaning. In this theory, students are transformed from passive receivers of knowledge to active constructors, that is, actively discovering information, and participating in processing information; and the identity of teachers is also changed from initiators and indoctrinators of knowledge into the instructors, facilitators, collaborators and helpers of students for knowledge construction. The research-oriented teaching model of the ideological and political course based on the network is mainly based on the constructivism learning theory. This model incorporates factors such as students, teachers, educational information, educational media, educational goals, and educational processes into an organically 
connected system that integrates knowledge transfer and various abilities into a range of specific teaching activities, both inside and outside the classroom (Ward, 2011).

\section{Humanistic theory}

Humanism emphasizes students' learning from doing and encourages them to actively explore and participate, so that students can truly become knowledge seekers and the subject of meaning construction. Humanism education emphasizes the students' subjectivity, initiative and autonomy study in learning and the openness of the learning content and learning methods. It emphasizes that students should gain knowledge and abilities through independent exploration and research. It encourages students to conduct researches in learning, to learn in the course of studies, and eventually learn how to gain knowledge, study and create (Paswan \& Ganesh, 2009). The teachers' task is to guide or help students, instead of training or teaching students in the traditional education.

\section{Design ideas of teaching model}

The research-based teaching model of the ideological and political course under the multimedia network environment is a new ternary teaching model that integrates the network environment, research-based learning, and ideological and political courses. It is conducive to the construction of an open learning environment and the students' role as the subject of learning, maximizing the realization of the organic integration between the network environment and classroom teaching model as well as strengthening the interaction between the teachers and students. In addition, through the use of multimedia and network technology, vast information amount in hypertext is input. The research-based teaching model means, based on the guidance of teachers, to adopt the collaboration approach, combine the course teaching content, and independently select research topics according to the text topic, make analysis and research, and write the research report by material collection and literature review (Kim \& Richarme, 2009; Li, 2012).

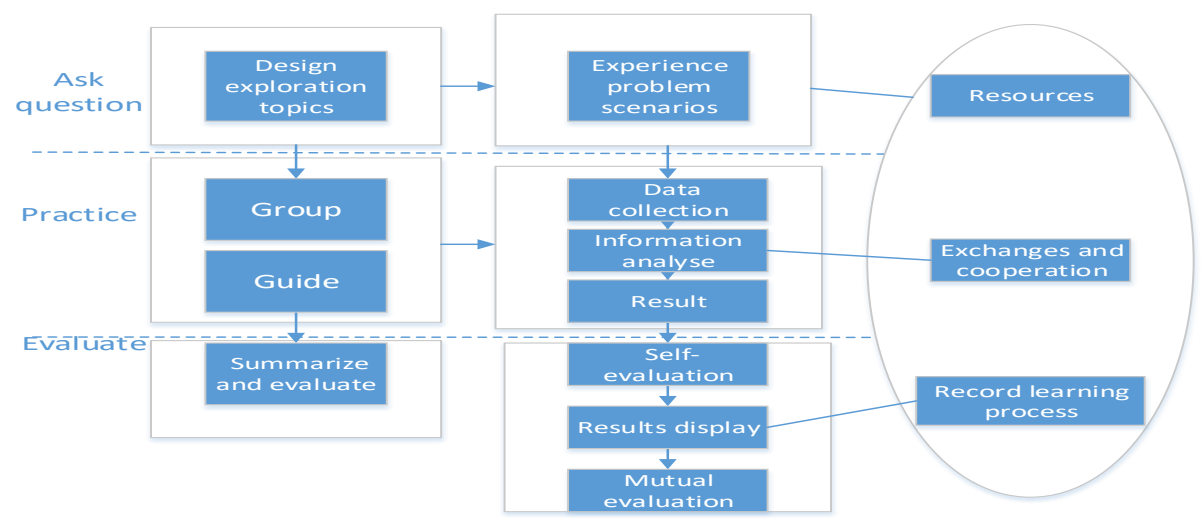

Figure 2. The main aspects and tasks of the teaching model. 
This teaching model can be summarized into the following main steps: 1) According to the text, determine the exploration topic (scene creation, schema inspiration); 2) Task design, division of responsibilities (data search, questionnaire survey, group discussion) 3) Autonomous learning, and questioning inquiry (teacher guidance, answers to difficult points) 4) Results display (ppt courseware, thesis) 5) Effectiveness evaluation (self-evaluation, peer review, teacher evaluation). The main aspects and tasks of the teaching model as shown in Figure 2.

\section{The Implementation Process and Practical Effect of the Research Teaching Model of the Ideological and Political Course under the Network Environment}

\section{Implementation process}

Firstly, at the topic selection stage, the students learn a certain amount of ideological and political course online according to the teacher's requirements, and then ask questions based on what they have learned and their own thinking or determine their research goals and tasks under the guidance of the teacher. Second, at the preparation stage, after the students identifies the research topics, teachers and students begin to enter the active preparation stage. Thirdly, at the implementation stage, the students by self-organization or group collaboration organize and analyse the collected data, solve problems through research-based learning, and then summarize and write the written reports or papers to form research-based learning results. At last, at the exchange and evaluation stage, students upload their results through multimedia to the results display platform for selfevaluation, peer review, and teacher evaluation.

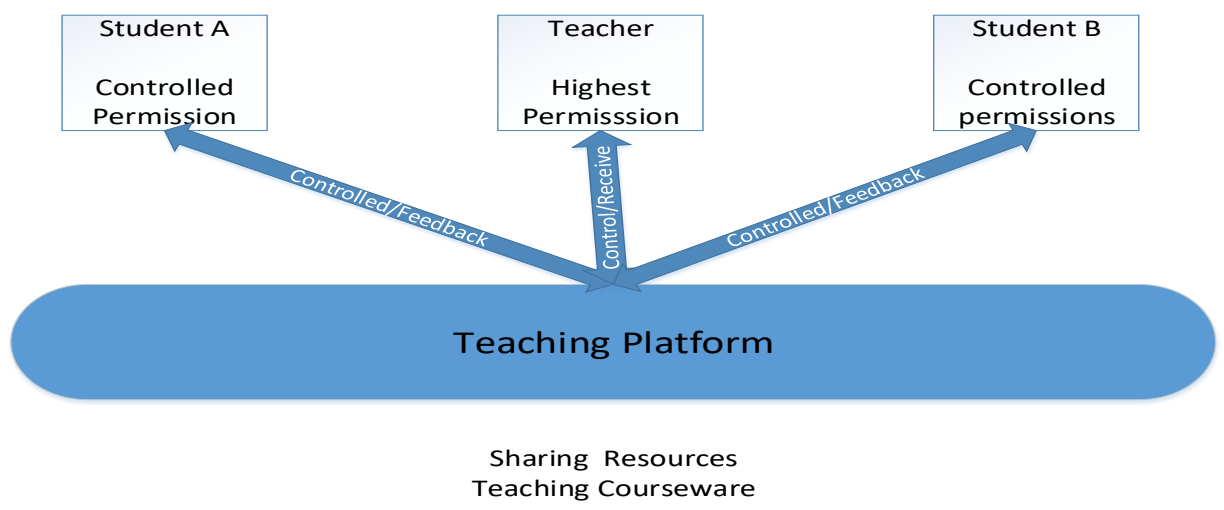

Figure 3. Implementation process.

\section{Teaching effect analysis}

One-year contrastive study was conducted in the teaching experiment. The two groups of students used the same teaching material, but in the different teaching models. The control group was conducted in the following normal teaching schedule: traditional classroom teaching was made four times a week, in which the comprehensive course occupied three classes hours per week, and listening and speaking one class hour per 
week; in addition, there were two class hours for autonomous learning on an extracurricular basis. For the experimental group, the multimedia computer environment was applied to expand the classroom teaching, and the input and output activities around the same topic were carried out in the curricular and extracurricular teaching, highlighting the learning purpose of the research output; it was performed according to the experimental design model. About the ideological and political course, the special topic teaching was adopted, with one topic every week in term of the teaching content (Theodorakis, Kambitsis \& Laios, 2012).

In this paper, the dynamic student model and its working principle in SQL learning were adopted. After the student logs in the system, the two-layer dynamic student model can be used to intelligently guide the students' experiments, learning, testing and other activities. The system generally selects the student model to drive the corresponding database and generates users' personalized experimental tasks, test topics, and learning resources etc.; by combining with the characteristics of the cognitive student model, the following data structure was designed in the SQL learning system to record students' cognitive ability:

$S M$

$=\{$ Knowledge,Comprehension, Application, Analysis, Synthesis, Evaluation, CorrectRate, ExAccuracy $\}$

where, Knowledge, Comprehensiveness, Application, Analysis, Synthesis, and Evaluation are the 6 parameters of cognitive ability, ExAccuracy and CorrectRate are the accuracy of the experiment and the correct rate of the test respectively.

The parameters of the student model are formed by the interaction between the system and the user. In the SQLlearning system, they are mainly recorded through the activities such as resource learning, normal experiment, and comprehensive testing. It should be noted that when the system designs experimental tasks and comprehensive testing topics, each item has undergone cognitive transformation, that is, each item has an observation point of cognitive ability; if the test item passes, then this observation point of cognitive ability shall be 1 ; if failed, it shall be -1 ; if not tested, it shall be 0 . Therefore, for each activity of the student, the related parameters reflecting one or more cognitive abilities are recorded in the student model database. The information on students' cognitive ability can be summarized from the transformed test items.

In the vector expression $S_{i}=\left(a_{1}, a_{2}, a_{3}, a_{4}, a_{5}, a_{6}\right), a_{i}$ is the correction rate of one certain cognitive ability; $a_{i}=\frac{R_{i j}(1)}{R_{i j}(1)+R_{i j}(-1)}$,

Where $0 \leq i \leq 6,0 \leq j \leq n ; \mathrm{n}$ is the number of all test questions performed by the student.

$R_{i j}(1)$ is the number of correct answers of the $\mathrm{i}$-th cognitive ability in the test so far.

$R_{i j}(-1)$ is the number of incorrect answers of the i-th cognitive ability in all tests so far.

The average value of each student's cognitive ability $a_{i}$ will be updated to the student model library at any time, while the average accuracy rate of CorrectRate and ExAccuracy will also be updated to the student model library. Simple weighted evaluation and classification of model parameters are made for the model parameters, and then the research-based learning results of the ideological and political course under the network environment can be evaluated. 
To verify the validity of the student model, 248 students were randomly divided into two groups. In the experimental group 168 students were selected in the SQL learning experimental teaching environment; in the control group 80 students were in the real experiment environment. With the same learning time, four tests were conducted (Table 1), where the average score of students in the experimental group was $16.29 \%$ higher than that of the control group. In the subsequent survey on recognition of student model, 152 valid questionnaires were received, of which the number of highly recognized, recognized, and unrecognized students was 109,38 , and 5 respectively; so the recognition of the student model in the experiment can reach up to $96.7 \%$ among the students. The result of experiment teaching as shown in Table 1.

Table 1

The Result of Experiment Teaching

\begin{tabular}{lcc}
\hline & Control Group & Experiment Group \\
\hline Test 1 & 76.5 & 89.2 \\
Test 2 & 69.8 & 81.8 \\
Test 3 & 82.2 & 96.8 \\
Test 4 & 73.4 & 83.3 \\
Mean Scores & 75.475 & 87.775 \\
\hline
\end{tabular}

\section{Conclusions}

The information society has brought college students a broader perspective, a more pluralistic choice of values, and a freer spiritual world, but also caused that "some college students have been faced with such problems in different degree as the confused political beliefs, unclear ideals and beliefs, distorted values, weak sense of integrity, lack of social responsibility, weakened spirit of hard struggle, poor unity and cooperation, and poor psychological quality”. The ideological and political education under computer network environment has completed a cycle of learning from classroom teaching to network teaching and then back to classroom teaching. In this process, teachers have fully played their guiding role, and also mobilized the enthusiasm of students to learn independently. The teacher's response to each student's question is not only a concern about his knowledge world, but also for his spiritual world, enabling students to exercise their independent thinking abilities, enhance their sense of social responsibility, and truly realize their thinking while acquiring new knowledge. Thus, the ideological and political course can truly realize the transformation from the teaching material system to teaching system.

\section{References}

Karatas, H., Alci, B., Balyer, A., \& Bademcioglu, M. (2016). An examination of students' perceptions of service quality dimensions in higher education. Anthropologist, 24(1), 389-398. http://dx.doi.org/10.1080/09720073.2016.11892030

Kim, J. W., \& Richarme, M. (2009). Applying the service-profit chain to internet service businesses. Journal of Service Science and Management, 2, 96-106. http://dx.doi.org/ 10.4236/jssm.2009.22013 
Lagrosen, S., Seyyed-Hashemi, R., \& Leitner, M. (2004). Examination of the dimensions of quality in higher education. Quality Assurance in Education, 12, 61-69. http://dx.doi.org/ 10.1108/09684880410536431

Lee, C. Y. (2012). Learning-by-doing in R\&D, knowledge threshold, and technological divide. Journal of Evolutionary Economics, 22(1), 109-132. http://dx.doi.org/10.1007/s00191-010-0202-4

Lee, J. W., \& Tai, S. W. (2008). Critical factors affecting customer satisfaction and higher education in Kazakhstan. International Journal of Management in Education, 2, 46-59. http://dx.doi.org/10.1504/IJMIE.2008.016230

Paswan, A. K., \& Ganesh, G. (2009). Higher education institutions: Satisfaction and loyalty among international students. Journal of Marketing for Higher Education, 19(1), 65-84. http://dx.doi.org/10.1080/08841240902904869

Raghavan, S., Ganesh, R., Raghavan, S., \& Ganesh, R. (2015). Addressing service quality to increase students' satisfaction and retention in Malaysian private higher education institutions. American Journal of Economics, 5(2), 243-250. http://dx.doi.org/10.5923/c.economics.201501.31

Theodorakis, N., Kambitsis, C., \& Laios, A. (2012). Relationship between measures of service quality and satisfaction of spectators in professional sports. Journal of Service Theory \& Practice, 11(6), 431-438. http://dx.doi.org/10.1108/09604520110410638

Ward, S. B. (2001). Intern supervision in school psychology: practice and process of field-based and university supervisors. School Psychology International, 22(3), 269-284. http://dx.doi.org/ $10.1177 / 0143034301223004$

Zhang, Z. (2016). Study on students' career planning of southwest petroleum university. Creative Education, 7(01), 152-158. http://dx.doi.org/10.4236/ce.2016.71015 